\title{
CALCIUM-DEPENDENT INACTIVATION OF NEURONAL CALCIUM CHANNEL CURRENTS IS INDEPENDENT OF CALCINEURIN
}

\author{
H. U. ZEILHOFER,* N. M. BLANK,* W. L. NEUHUBER $\dagger$ and D. SWANDULLA* $*$ \\ *Institut für Experimentelle und Klinische Pharmakologie und Toxikologie, Fahrstrasse 17 and †Institut für Anatomie, Universität \\ Erlangen-Nürnberg, Kraukenhausstrasse 9, D-91054 Erlangen, Germany
}

\begin{abstract}
Dephosphorylation by the $\mathrm{Ca}^{2+} /$ calmodulin-dependent phosphatase calcineurin has been suggested as an important mechanism of $\mathrm{Ca}^{2+}$-dependent inactivation of voltage-gated $\mathrm{Ca}^{2+}$ channels. We have tested whether calcineurin plays a role in the inactivation process of two types of high-voltage-activated $\mathrm{Ca}^{2+}$ channels ( $\mathrm{L}$ and $\mathrm{N}$ type) widely expressed in the central nervous system, using the immunosuppressive drug FK506 (tacrolimus), which inhibits calcineurin after binding to intracellular FK506 binding proteins. Inactivation of L- and N-type $\mathrm{Ca}^{2+}$ channels was studied in a rat pituitary tumor cell line $\left(\mathrm{GH}_{3}\right)$ and chicken dorsal root ganglion neurons, respectively. With the use of antisera directed against the calcineurin subunit B and the 12,000 mol. wt binding protein, we show that both proteins are present in the cytoplasm of $\mathrm{GH}_{3}$ cells and chicken dorsal root ganglion neurons. Ionic currents through voltage-gated $\mathrm{Ca}^{2+}$ channels were investigated in the perforated-patch and whole-cell configurations of the patch-clamp technique. The inactivation of $\mathrm{L}$ - as well as $\mathrm{N}$-type $\mathrm{Ca}^{2+}$ currents could be well fitted with a bi-exponential function. Inactivation was largely reduced when $\mathrm{Ba}^{2+}$ substituted for extracellular $\mathrm{Ca}^{2+}$ or when the $\mathrm{Ca}^{2+}$ chelator EGTA was present intracellularly, indicating that both types of $\mathrm{Ca}^{2+}$ currents exhibited $\mathrm{Ca}^{2+}$-dependent inactivation. Extracellular (perforated-patch configuration) or intracellular (whole-cell configuration) application of FK506 to inactivate calcineurin had no effect on the amplitude and time-course of $\mathrm{Ca}^{2+}$ channel current inactivation of either $\mathrm{L}$ - or N-type $\mathrm{Ca}^{2+}$ channels. In addition, we found that recovery from inactivation and rundown of N-type $\mathrm{Ca}^{2+}$ channel currents were not affected by FK506.

Our results provide direct evidence that the calcium-dependent enzyme calcineurin is not involved in the inactivation process of the two $\mathrm{Ca}^{2+}$ channel types which are important for neuronal functioning, such as gene expression and transmitter release. (C) 1999 IBRO. Published by Elsevier Science Ltd.
\end{abstract}

Key words: $\mathrm{Ca}^{2+}$ channel, inactivation, calcineurin, FK506, FKBP.

An increase in the intracellular concentration of free $\mathrm{Ca}^{2+}$ $\left(\left[\mathrm{Ca}^{2+}\right]_{\mathrm{i}}\right)$ plays a pivotal role in a large variety of physiological functions, such as excitation-secretion coupling and neuronal plasticity. On the other hand, excessive increases in $\left[\mathrm{Ca}^{2+}\right]_{\mathrm{i}}$ may lead to excitotoxic cell death, which occurs, for example, during brain ischemia and epileptic seizures. ${ }^{16}$ In neurons, one important pathway that leads to an increase in $\left[\mathrm{Ca}^{2+}\right]_{\mathrm{i}}$ is the opening of voltage-gated $\mathrm{Ca}^{2+}$ channels in the plasma membrane. The activity of these $\mathrm{Ca}^{2+}$ channels is effectively regulated by G-protein-coupled receptors and by $\mathrm{Ca}^{2+}$ - and voltage-dependent inactivation of these ion channels. ${ }^{3,13,40}$ Among the different types of $\mathrm{Ca}^{2+}$ channels, $\mathrm{Ca}^{2+}$-dependent inactivation is best documented for L-type $\mathrm{Ca}^{2+}$ channels. ${ }^{2,23,24,34,46}$ However, a $\mathrm{Ca}^{2+}$-mediated component of $\mathrm{Ca}^{2+}$ channel inactivation has also been described for N-type channels (e.g., Ref. 25).

Different mechanisms have been proposed for $\mathrm{Ca}^{2+}$-dependent inactivation of neuronal $\mathrm{Ca}^{2+}$ channels. One hypothesis which is still widely accepted is that inactivation of $\mathrm{Ca}^{2+}$ channels is mediated, at least in part, by enzymes. Dephosphorylation by the $\mathrm{Ca}^{2+} /$ calmodulin-dependent serine/threonine phosphatase calcineurin $(\mathrm{CaN})$, also known as phosphatase $2 \mathrm{~B}$, has originally been proposed as the enzymatic mechanism

$¥$ To whom correspondence should be addressed. Tel.: +49-9131-8526879; fax: + 49-9131-85-22774.

E-mail address: swandulla@pharmakologie.uni-erlangen.de (D. Swandulla) Abbreviations: $\left[\mathrm{Ca}^{2+}\right]_{\mathrm{i}}$, intracellular free $\mathrm{Ca}^{2+}$ concentration; CaN, calcineurin; CaN-B, B subunit of calcineurin; DRG, dorsal root ganglion; EGTA, ethyleneglycolbis( $\beta$-aminoethyl ether)- $N, N, N^{\prime}, N^{\prime}$-tetra-acetate; FKBP, FK506 binding protein; FKBP-12, 12,000 mol. wt FK506 binding protein; HEPES, $N$-2-hydroxyethylpiperazine- $N$-2-ethanesulfonic acid; TBS, Tris-buffered saline. for inactivation of neuronal $\mathrm{Ca}^{2+}$ channels in both molluscan and mammalian neurons ${ }^{9}$ (for a review see Armstrong and Eckert $^{5}$ ). Overexpression of human $\mathrm{CaN}$ in rodent neuroblastoma $\times$ glioma hybrid cells increased the $\mathrm{Ca}^{2+}$-dependent inactivation of $\mathrm{N}$-type and, to a lesser degree, $\mathrm{L}$-type $\mathrm{Ca}^{2+}$ channels. ${ }^{32} \mathrm{~A}$ physiological significance of this phenomenon is suggested by the observation that $\mathrm{CaN}$ and voltage-gated $\mathrm{Ca}^{2+}$ channels are co-localized in dorsal root ganglion cells. ${ }^{31}$ Such a phosphatase-mediated mechanism of inactivation could counteract the well known up-regulation of L-type $\mathrm{Ca}^{2+}$ channels by phosphorylation via cyclic-AMP-dependent protein kinase. $^{3}$

We have tested the possible involvement of $\mathrm{CaN}$ in the $\mathrm{Ca}^{2+}$-dependent inactivation of $\mathrm{L}$ - and $\mathrm{N}$-type $\mathrm{Ca}^{2+}$ channels in rat pituitary tumor $\left(\mathrm{GH}_{3}\right)$ cells and chicken dorsal root ganglion (DRG) neurons using the specific $\mathrm{CaN}$ inhibitor FK506. ${ }^{30}$ This immunosuppressive drug forms an inactive tertiary complex with $\mathrm{CaN}$ after binding to intracellular receptor proteins called FK506 binding proteins (FKBPs). We found that CaN and at least the 12,000 mol. wt FKBP (FKBP-12) are present in $\mathrm{GH}_{3}$ cells and in chicken DRG neurons. Application of FK506, however, had no effect on amplitudes and inactivation kinetics of $\mathrm{Ca}^{2+}$ channel currents in either $\mathrm{GH}_{3}$ or chicken DRG neurons, suggesting that $\mathrm{CaN}$ is not involved in $\mathrm{L}$ - or $\mathrm{N}$-type $\mathrm{Ca}^{2+}$ channel inactivation in these cells.

\section{EXPERIMENTAL PROCEDURES}

\section{Cell preparation}

$\mathrm{GH}_{3}$ cells (American Type Culture Collection, Rockville, U.S.A.) were grown in 35-mm tissue culture dishes (Nunc, Wiesbaden, 
Germany) at $37^{\circ} \mathrm{C}$ in a humidified $5 \% \quad \mathrm{CO}_{2} / 95 \%$ air atmosphere in minimum essential medium supplemented with $10 \%$ fetal calf serum, $0.3 \%$ D-glucose, $2 \mathrm{mM}$ L-glutamine, $25 \mathrm{U} / \mathrm{ml}$ penicillin and $25 \mathrm{mg} / \mathrm{ml}$ streptomycin.

Dissociated cultures of chicken DRG neurons were prepared as described previously. ${ }^{39}$ Briefly, sensory ganglia from 10 - to 12 -dayold chick embryos were dissociated by gentle trituration after a $20-\mathrm{min}$ incubation at $37^{\circ} \mathrm{C}$ in $\mathrm{Ca}^{2+}$-free Spinner salt solution containing $0.1 \%$ trypsin. Dissociated cells were plated on poly-D-lysine-coated glass coverslips and maintained in Eagle's basal medium supplemented with $10 \%$ horse serum, $0.3 \%$ D-glucose, $2 \mathrm{mM}$ L-glutamine, $25 \mathrm{U} / \mathrm{ml}$ penicillin and $25 \mathrm{mg} / \mathrm{ml}$ streptomycin.

\section{Immunocytochemistry and confocal microscopy}

$\mathrm{GH}_{3}$ cells were plated on poly-D-lysine-coated slides. Monolayers were fixed with $4 \%$ formaldehyde/phosphate-buffered saline for $10 \mathrm{~min}$ at $4^{\circ} \mathrm{C}$ and permeabilized with acetone $(100 \%)$ at $18^{\circ} \mathrm{C}$. Nonspecific protein binding sites were blocked with $10 \%$ fetal calf serum for $30 \mathrm{~min}$ at room temperature. Cells were then incubated with the respective antibodies (dilution 1:50) overnight at $4^{\circ} \mathrm{C}$. FKBP was stained with an antiserum raised against a consensus sequence of human FKBP-12; CaN was stained with a polyclonal antiserum directed against the regulatory subunit of $\mathrm{CaN}$ (CaN-B). After intensive washing, monolayers were incubated with fluorescein isothiocyanate-tagged goat anti-rabbit immunoglobulin $\mathrm{G}$ antibodies for $3 \mathrm{~h}$ at room temperature. Single optical sections about $400 \mathrm{~nm}$ thick were taken with a Biorad MRC 1000 confocal microscope attached to a Nikon Diaphot 300 equipped with an oil immersion objective lens ( $\times 60$ ) of 1.4 numerical aperture using the $488 \mathrm{~nm}$ line of a kryptonargon laser.

Chick embryos at embryonic day 12 were fixed in $4 \%$ formaldehyde/ phosphate-buffered saline and cryosectioned at $12 \mu \mathrm{m}$. Cryostat sections were mounted on poly-L-lysine-coated slides and incubated after a blocking step with $1 \%$ bovine serum albumin, $5 \%$ goat normal serum and $0.5 \%$ Triton X-100 in Tris-buffered saline (TBS) with rabbit anti-CaN or rabbit anti-FKBP-12 at a dilution of 1:100 in TBS overnight at room temperature. After buffer rinse, a Cy3-tagged goat antirabbit immunoglobulin $\mathrm{G}$ diluted 1:800 in TBS was applied for $1 \mathrm{~h}$ at room temperature. After a final buffer rinse, the sections were coverslipped in TBS/glycerol (1:1) at $\mathrm{pH}$ 8.6. Photodocumentation was done using a Leica Aristoplan epifluorescence microscope equipped with filtercube N2.1 and Kodak Tmax 400 black and white film. Control experiments included omission of the primary antiserum, application of normal rabbit serum and incubation with primary antiboby preabsorbed with the relevant antigen.

\section{Electrophysiology}

Electrophysiological experiments were performed at room temperature in acutely dissociated chicken DRG neurons and $\mathrm{GH}_{3}$ cells $3-12 \mathrm{~h}$ and two to seven days after plating, respectively. Ionic currents were recorded either in the whole-cell ${ }^{19}$ or perforated-patch configuration ${ }^{22}$ of the patch-clamp technique using an EPC-7 amplifier (List Electronics, Pfungstadt, Germany). Pipettes pulled from borosilicate glass (KIMAX 51, Kimble, U.S.A.) and fire polished had resistances of 2-3 M $\Omega$ in standard recording solutions. The standard extracellular solution contained (in $\mathrm{mM}$ ): $145 \mathrm{NaCl}, 5 \mathrm{KCl}, 5 \mathrm{CaCl}_{2}, 2 \mathrm{MgCl}_{2}, 10$ HEPES, 10 D-glucose ( $\mathrm{pH} 7.30$ ), adjusted with $\mathrm{NaOH}$. To record ionic currents through $\mathrm{Ca}^{2+}$ channels in isolation from $\mathrm{Na}^{+}$currents, $1 \mu \mathrm{M}$ tetrodotoxin was added to the external solution. In some experiments, $5 \mathrm{mM} \mathrm{CaCl}_{2}$ was substituted with $5 \mathrm{mM} \mathrm{BaCl}_{2}$.

The standard internal solution contained (in $\mathrm{mM}$ ): $120 \mathrm{CsCl}, 20$ tetraethylammonium chloride, $2 \mathrm{MgCl}_{2}, 3 \mathrm{Na}_{2} \mathrm{ATP}, 0.2 \mathrm{Na}_{2} \mathrm{GTP}, 5$ EGTA, 10 HEPES (pH 7.30), adjusted with $\mathrm{CsOH}$. In some experiments, $1 \mathrm{mM}$ EGTA was used instead of $5 \mathrm{mM}$ EGTA. To obtain perforated patches, nystatin $(150 \mu \mathrm{g} / \mathrm{ml}, 0.3 \%$ dimethyl sulfoxide) was added to the pipette solution and $\mathrm{Na}_{2} \mathrm{ATP}$ and $\mathrm{Na}_{2} \mathrm{GTP}$ were omitted.

\section{Materials}

Antisera directed against FKBP-12 and $\mathrm{CaN}$ were from ABR (Golden, CO, U.S.A.). Fluorescein isothiocyanate-tagged goat antirabbit immunoglobulin $\mathrm{G}$ antibodies were from Dianova (Hamburg, Germany). Cy3-tagged goat anti-rabbit immunoglobulin $\mathrm{G}$ was also from Dianova. FKBP-12 was from Sigma Chemie (Deisenhofen,
Germany). FK506 (Calbiochem, Bad Soden, Germany) and nifedipine (a gift from Bayer, Leverkusen, Germany) were dissolved in dimethyl sulfoxide.

\section{RESULTS}

Expression and cellular distribution of calcineurin and FKBP-12

In $\mathrm{GH}_{3}$ cells, both cytosol and nucleus were homogeneously stained by a polyclonal antiserum directed against FKBP-12 (Fig. 1A). In control experiments, staining was almost completely prevented by preabsorbtion of the primary antibody with FKBP-12. CaN immunoreactivity was detected using a polyclonal antiserum from rabbit which recognizes $\mathrm{CaN}-\mathrm{B}$. Immunoreactivity against $\mathrm{CaN}$ was detected in the cytosol and in the nucleus of $\mathrm{GH}_{3}$ cells (Fig. 1C).

In DRGs of chick embryos (embryonic day 12), there was a homogeneous cytoplasmic immunostaining in a majority of neuronal cell bodies for both FKBP-12 (Fig. 1B) and CaN-B (Fig. 1D). There was also immunoreactivity in axons of dorsal roots and spinal nerves. Within the spinal cord, neuropil of both ventral and dorsal horns displayed intense immunostaining for CaN-B, but not for FKBP-12.

\section{Inactivation of l-type calcium channel currents}

In a first set of experiments, $\mathrm{Ca}^{2+}$ current inactivation was studied in $\mathrm{GH}_{3}$ cells. These cells possess mainly L-type (and T-type) $\mathrm{Ca}^{2+}$ channels. ${ }^{36}$ In these experiments, ionic currents through voltage-gated $\mathrm{Ca}^{2+}$ channels were recorded using the perforated-patch configuration of the patch-clamp technique with either $\mathrm{Ca}^{2+}$ or $\mathrm{Ba}^{2+}$ as the charge carrier. This approach was chosen since it prevents the washout of intracellular constituents which may influence $\mathrm{Ca}^{2+}$ channel inactivation or which may be necessary for the inhibitory effect of FK506 on CaN. Figure 2A shows averages of 10 current traces evoked by $200-\mathrm{ms}$ depolarizations to $0 \mathrm{mV}$ from a resting potential of $-40 \mathrm{mV}$. This holding potential was chosen to record high-voltage-activated $\mathrm{Ca}^{2+}$ channel currents in isolation from low-voltage-activated $\mathrm{Ca}^{2+}$ currents. Under these experimental conditions, inward currents carried by $\mathrm{Ca}^{2+}$ ions had amplitudes in the range of $20 \mathrm{pA}$, inactivated by about $60 \%$ within $150 \mathrm{~ms}$ and were completely blocked by $100 \mu \mathrm{M}$ $\mathrm{Cd}^{2+}$ or by $10 \mu \mathrm{M}$ nifedipine (not shown). Inactivation was nearly absent when $\mathrm{Ca}^{2+}$ was substituted by $\mathrm{Ba}^{2+}$.

With $\mathrm{Ca}^{2+}$ as the charge carrier, $\mathrm{Ca}^{2+}$ channel currents could be well fitted to a double exponential function, with time constants $\tau_{1}=11.4 \pm 0.6 \mathrm{~ms}$ and $\tau_{2}=116 \pm 12 \mathrm{~ms}$ (mean \pm S.E.M., $\quad n=10$ ). Extracellular application of FK506 (10 $\mu \mathrm{M}, n=5)$ had no significant effect on either amplitude or current decay kinetics (Fig. 2B, Table 1), suggesting that $\mathrm{CaN}$ was not involved in the inactivation of $\mathrm{Ca}^{2+}$ channel currents in $\mathrm{GH}_{3}$ cells (also see Victor et al. ${ }^{42}$ ).

\section{Inactivation of $N$-type calcium channel currents}

$\mathrm{Ca}^{2+}$ current inactivation was further studied in chicken DRG neurons. The high-voltage-activated $\mathrm{Ca}^{2+}$ channel currents in these cells belong mainly to the $\omega$-conotoxin GVIA-sensitive $\mathrm{N}$ type. ${ }^{7}$ In these cells, conventional wholecell patch-clamp recordings were performed, which allowed us to dialyse the cells with a known concentration of FK506 and in some experiments also with a complex of FK506 and FKBP-12. $\mathrm{Ca}^{2+}$ channel currents were again elicited by 

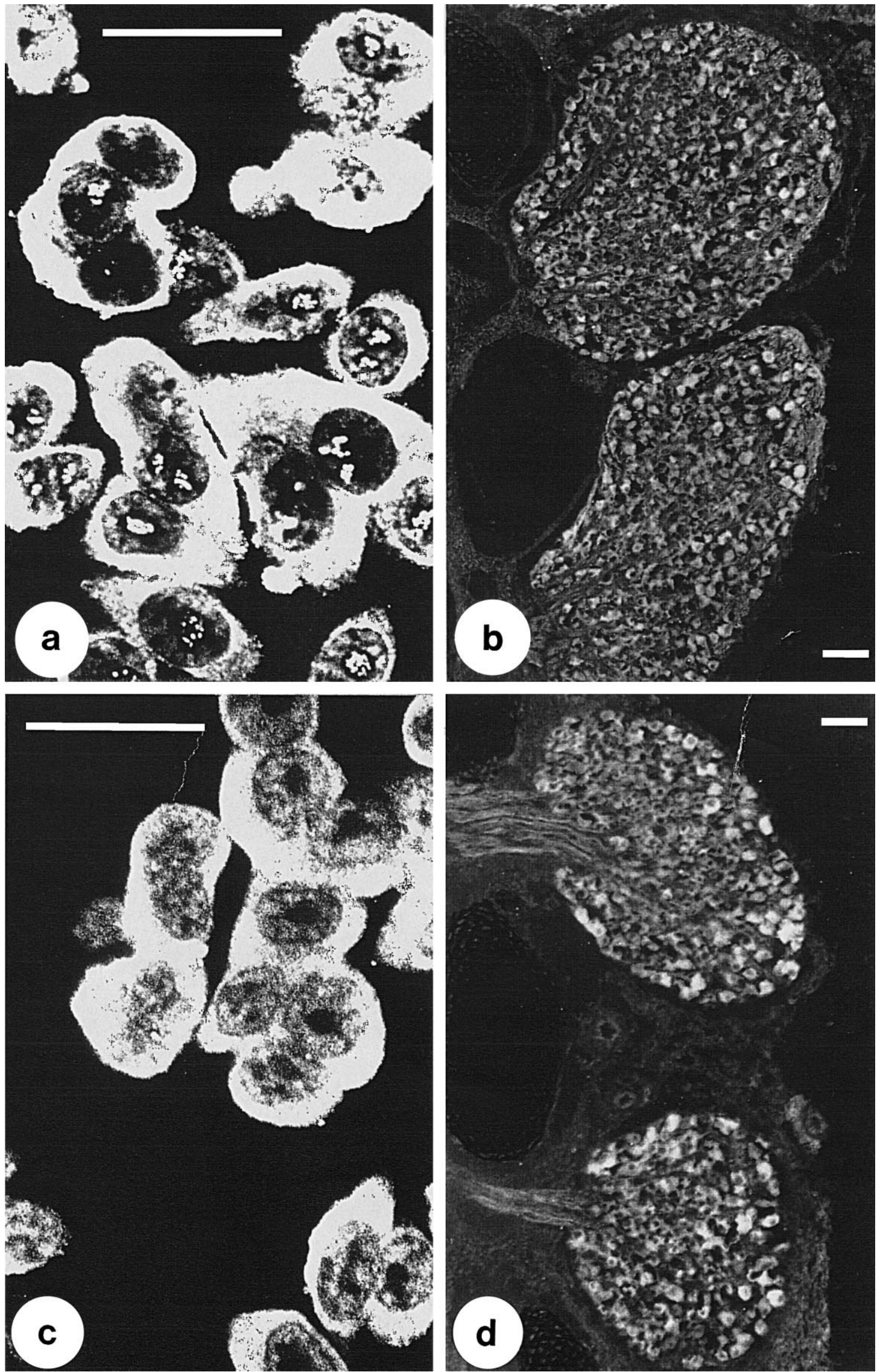

Fig. 1. Immunocytochemical detection of FKBP-12 (a, b) and CaN (c, d) in $\mathrm{GH}_{3}$ cells $(\mathrm{a}, \mathrm{c})$ and chick embryonic DRG cells (b, d). In DRGs, the majority of neurons and dorsal root axons (d, to the left) are labeled. Due to the confocal imaging process, the heterochromatin of the nucleolus of $\mathrm{GH}_{3}$ cells stays out in black (a, c). Note granular immunostaining for FKBP in the nucleolus of $\mathrm{GH}_{3}$ cells (a). a and c are confocal images, b and d conventional epifluorescence micrographs. Scale bars $=50 \mu \mathrm{m}(\mathrm{a}, \mathrm{c}), 100 \mu \mathrm{m}(\mathrm{b}, \mathrm{d})$ 
A

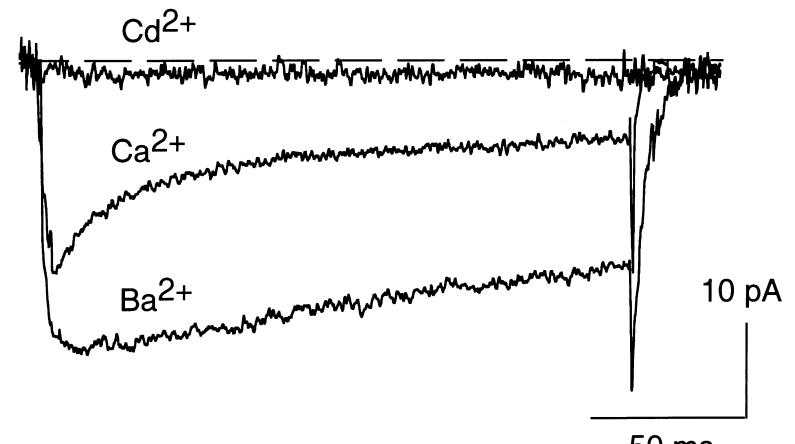

B

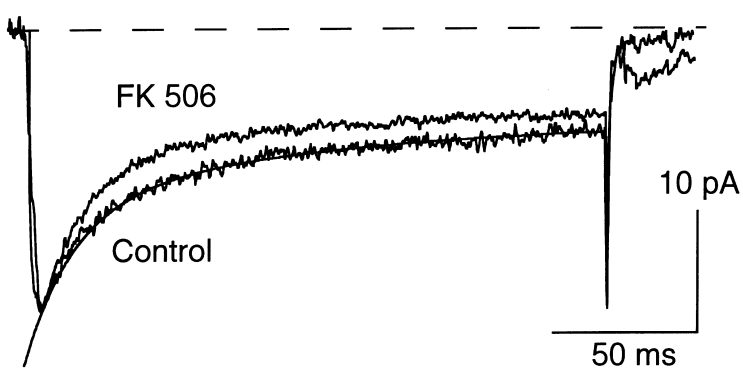

Fig. 2. $\mathrm{Ca}^{2+}$ current inactivation in $\mathrm{GH}_{3}$ cells. Ionic currents through voltage-gated $\mathrm{Ca}^{2+}$ channels were recorded using the perforated-patch configuration of the patch-clamp technique with either $\mathrm{Ca}^{2+}$ or $\mathrm{Ba}^{2+}$ as the charge carrier. A and B show averages of 10 consecutively recorded current traces. (A) With $5 \mathrm{mM}$ external $\mathrm{Ca}^{2+}$ as the charge carrier, inward currents elicited by a 200 -ms voltage step from -40 to $0 \mathrm{mV}$ had peak amplitudes of about $20 \mathrm{pA}$. These currents were completely blocked by application of $100 \mu \mathrm{M} \mathrm{Cd}^{2+}$ and exhibited pronounced inactivation during the depolarization. When $\mathrm{Ca}^{2+}$ was substituted by $5 \mathrm{mM} \mathrm{Ba}^{2+}$, inactivation was largely reduced from about $60 \%$ in the presence of $\mathrm{Ca}^{2+}$ to less than $30 \%$. (B) When $\mathrm{Ca}^{2+}$ was used as the charge carrier, inactivation kinetics could be well fitted using a double exponential function of the form $I(t)=A-B \exp (-t / 15 \mathrm{~ms})-C \exp (-t / 89 \mathrm{~ms})$ in these experiments. External application of FK506 for 10 min had no significant effect on the time-course of inactivation.

depolarizing voltage steps from -40 to $0 \mathrm{mV}$ for several hundred milliseconds. With $5 \mathrm{mM}$ external $\mathrm{Ca}^{2+}$ as the charge carrier, currents had amplitudes of 1-2 nA. To test for the $\mathrm{Ca}^{2+}$ dependence of inactivation, the neurons were dialysed with different concentrations of the $\mathrm{Ca}^{2+}$ chelator EGTA (1 and $5 \mathrm{mM}$ ). With $1 \mathrm{mM}$ EGTA, $\mathrm{Ca}^{2+}$ currents inactivated again in a bi-exponential manner, with time constants $\tau_{1}=39 \pm 6 \mathrm{~ms}$ and $\tau_{2}=400 \pm 39 \mathrm{~ms}(n=10)$. When $5 \mathrm{mM}$ EGTA was used, time constants increased significantly to $\tau_{1}=145 \pm 29 \mathrm{~ms}$ and $\tau_{2}=936 \pm 163 \mathrm{~ms} \quad(n=5)$, respectively. FK506 (10 $\mathrm{MM}$, internally applied) again had no significant effect on $\mathrm{Ca}^{2+}$ current inactivation under these conditions $\left(\tau_{1}=48 \pm 5.3 \mathrm{~ms}\right.$ and $\tau_{2}=474 \pm 43 \mathrm{~ms}, n=9$; Fig. 3, Table 1). Similar results were obtained when the cells were perfused with the complex of FK506 and FKBP12 (1 $\mu \mathrm{M})$.

\section{Recovery from inactivation}

Although the involvement of $\mathrm{CaN}$ in the inactivation process of $\mathrm{Ca}^{2+}$ channels during a depolarizing voltage step appears unlikely from our experiments, this enzyme may still influence the ratio of phosphorylated and unphosphorylated channels on a longer time scale. We have therefore tested whether FK506 speeds up the recovery of $\mathrm{Ca}^{2+}$ channel currents from inactivation. In these experiments, $\mathrm{Ca}^{2+}$

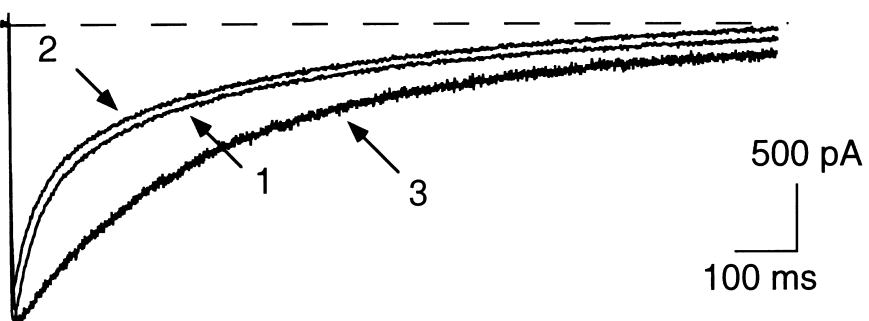

Fig. 3. $\mathrm{Ca}^{2+}$ current inactivation in chicken DRG cells. $\mathrm{Ca}^{2+}$ currents evoked from a holding potential of $-40 \mathrm{mV}$ to $0 \mathrm{mV}$ for $1 \mathrm{~s}$ are shown from three different cells with similar $\mathrm{Ca}^{2+}$ current amplitudes. With $1 \mathrm{mM}$ EGTA, $\mathrm{Ca}^{2+}$ currents exhibited pronounced inactivation (1). When FK 506 $(10 \mu \mathrm{M})$ was added to the internal solution, the inactivation time-course was very similar (2), whereas increasing the intracellular EGTA concentration to $5 \mathrm{mM}$ strongly reduced $\mathrm{Ca}^{2+}$ current inactivation (3).

currents were elicited at increasing intervals (20 ms to $25 \mathrm{~s}$ ) after a depolarizing prepulse to $0 \mathrm{mV}$ for $2 \mathrm{~s}$ (Fig. 4A). With $5 \mathrm{mM}$ EGTA in the internal solution, $\mathrm{Ca}^{2+}$ channel currents inactivated by about $85 \%$ within 2 s. Recovery from inactivation occurred with a double-exponential time-course, with time constants of about $600 \mathrm{~ms}$ and $10 \mathrm{~s}$. The maximum recovery obtained was different in control cells and cells treated with FK506 (86\% and 63\%, respectively). Despite this difference, neither the slow nor the fast time constant of the $\mathrm{Ca}^{2+}$ current recovery were significantly changed when FK506 $(10 \mu \mathrm{M})$ was added to the internal solution. Time constants of recovery were, on average, $660 \mathrm{~ms}$ (control, $n=4$ ) versus $570 \mathrm{~ms}$ (FK506, $n=5$ ), and $8.93 \mathrm{~s}$ versus $10.8 \mathrm{~s}$ for the fast and slow processes (Fig. 4B). Similar results were obtained when FK506 was applied extracellularly (not shown).

\section{Rundown}

A second phenomenon possibly related to phosphorylation is the so-called rundown or washout of high-voltage-activated $\mathrm{Ca}^{2+}$ channels. ${ }^{6,12,15,27}$ Since the gradual loss of $\mathrm{Ca}^{2+}$ channel current amplitude could be slowed down or reversed by addition of ATP, $\mathrm{Mg}^{2+}$, cyclic-AMP or the catalytic subunit of protein kinase A to the intracellular medium, a loss of phosphorylation has been suggested as the underlying mechanism of rundown. We have investigated whether $\mathrm{CaN}$ is involved in this phenomenon in chick DRG neurons. Cells were dialysed with $\mathrm{Ca}^{2+} / \mathrm{Ca}^{2+}$-EGTA buffers with different free $\mathrm{Ca}^{2+}$ concentrations. The time-course of $\mathrm{Ca}^{2+}$ current rundown was faster with $\left[\mathrm{Ca}^{2+}\right]_{\mathrm{i}}$ of about $200 \mathrm{nM}$ as compared to virtually $\mathrm{Ca}^{2+}$-free solutions (Fig. 5), suggesting that a $\mathrm{Ca}^{2+}$-dependent enzyme like the $\mathrm{Ca}^{2+}$-dependent phosphatase $\mathrm{CaN}$ or a $\mathrm{Ca}^{2+}$-dependent protease could be involved. By adding FK506, we have tested a possible role of $\mathrm{CaN}$ in the rundown process. Intracellular application of FK506 $(10 \mu \mathrm{M})$ did not prevent the rundown, but instead slightly facilitated the loss of the $\mathrm{Ca}^{2+}$ current amplitudes.

\section{DISCUSSION}

Several studies have clearly demonstrated that at least Ltype $\mathrm{Ca}^{2+}$ channels, both in neurons and in the heart, are regulated via phosphorylation, ${ }^{2,4,5}$ which affects both the number of available ion channels and the channel open time. ${ }^{34,41,45}$ Many investigators have proposed that the 
A

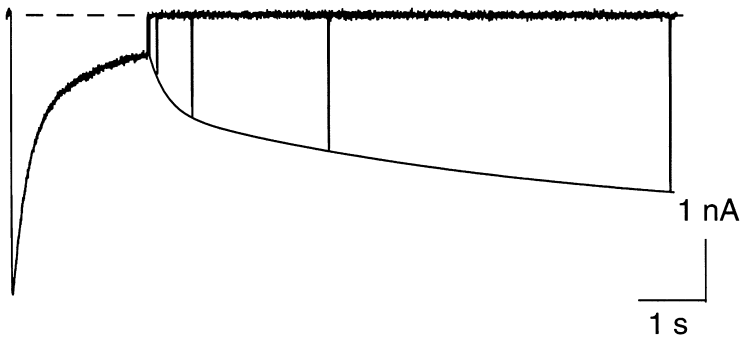

B

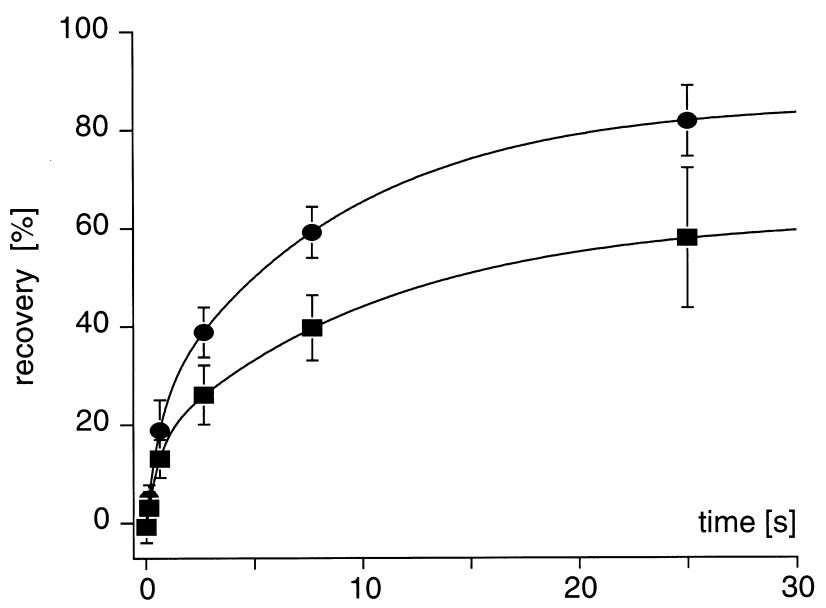

Fig. 4. Recovery from $\mathrm{Ca}^{2+}$ channel inactivation in chicken DRG neurons. (A) Recovery from $\mathrm{Ca}^{2+}$ channel inactivation was tested after a depolarizing prepulse from -40 to $0 \mathrm{mV}$ for $2 \mathrm{~s}$ by short $(15 \mathrm{~ms})$ depolarizations to $0 \mathrm{mV}$ after time intervals of $0.020,0.145,0.600,2.66$ and $7.67 \mathrm{~s}$. The line represents a double-exponential fit $\left(\tau_{1}=322 \mathrm{~ms}\right.$ and $\left.\tau_{2}=6.6 \mathrm{~s}\right)$ of the peak $\mathrm{Ca}^{2+}$ current amplitudes recorded during the recovery process. (B) Percentage of recovered $\mathrm{Ca}^{2+}$ current amplitude versus logarithmic time (means \pm S.E.M.). The lines represent double-exponential fits to the data points. (๑) Control, $f(t)=85.9 \mathrm{pA}-23.3 \mathrm{pA} \exp (-t / 66 \mathrm{~ms})-62.7 \exp$ $(-t / 8930 \mathrm{~ms}), \quad n=4 ; \quad(\square) \quad$ internal FK506 $(1 \mu \mathrm{M})$, $f(t)=62.2 \mathrm{pA}-17.2 \mathrm{pA} \exp (-\mathrm{t} / 0.570 \mathrm{~s})-46.7 \mathrm{pA} \exp (-t / 10.8 \mathrm{~s}), n=5$.

Table 1. Time constants (mean \pm S.E.M.) of $\mathrm{Ca}^{2+}$ channel current inactivation in dorsal root ganglion and $\mathrm{GH}_{3}$ cells under different experimental conditions

\begin{tabular}{lcc}
\hline & $\tau_{\text {fast }}(\mathrm{ms})$ & $\tau_{\text {slow }}(\mathrm{ms})$ \\
\hline GH 3 cells (perforated-patch configuration) & & \\
Control & $11.4 \pm 0.6$ & $116 \pm 12$ \\
FK506 $(10 \mu \mathrm{M})$ & $12.7 \pm 0.7$ & $85.0 \pm 5.8$ \\
& & \\
DRG cells (whole-cell configuration) & $145 \pm 29$ & $936 \pm 163$ \\
EGTA $(5 \mathrm{mM})$ & $39 \pm 6$ & $400 \pm 39$ \\
EGTA $(1 \mathrm{mM})$ & $48 \pm 5.3$ & $474 \pm 43$ \\
EGTA $(1 \mathrm{mM}) /$ FK506 $(10 \mu \mathrm{M})$ & &
\end{tabular}

inactivation of L-type $\mathrm{Ca}^{2+}$ channels might be due to a loss of the number of phosphorylated channels and a strong candidate for an enzyme that could mediate this process is the $\mathrm{Ca}^{2+}$-calmodulin-dependent phosphatase CaN. ${ }^{26}$ Similar mechanisms have been proposed for $\mathrm{N}$-type $\mathrm{Ca}^{2+}$ channels. ${ }^{1,18,20,21,33,44}$

Within the CNS, CaN is abundantly expressed ${ }^{10}$ and constitutes about $1 \%$ of the total brain protein. ${ }^{26}$ Inhibition of $\mathrm{CaN}$ by FK506 and cyclosporin A has been reported to increase the spontaneous neuronal firing rate observed in rat cortices. ${ }^{43}$
A

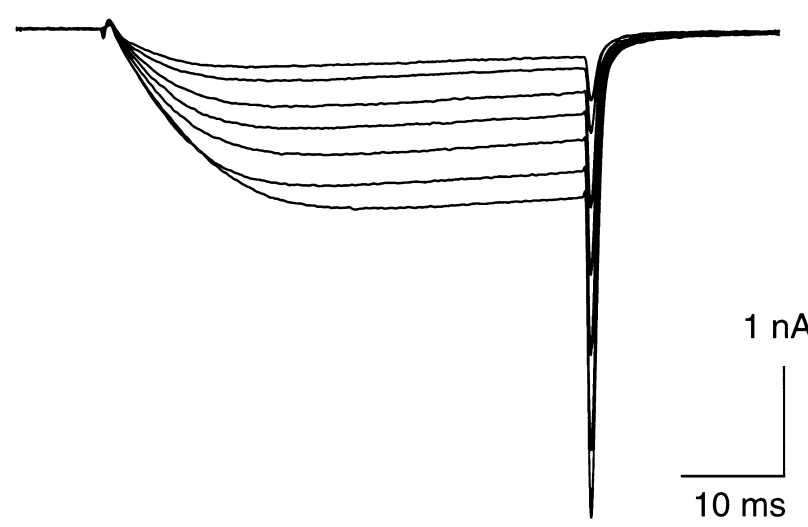

B

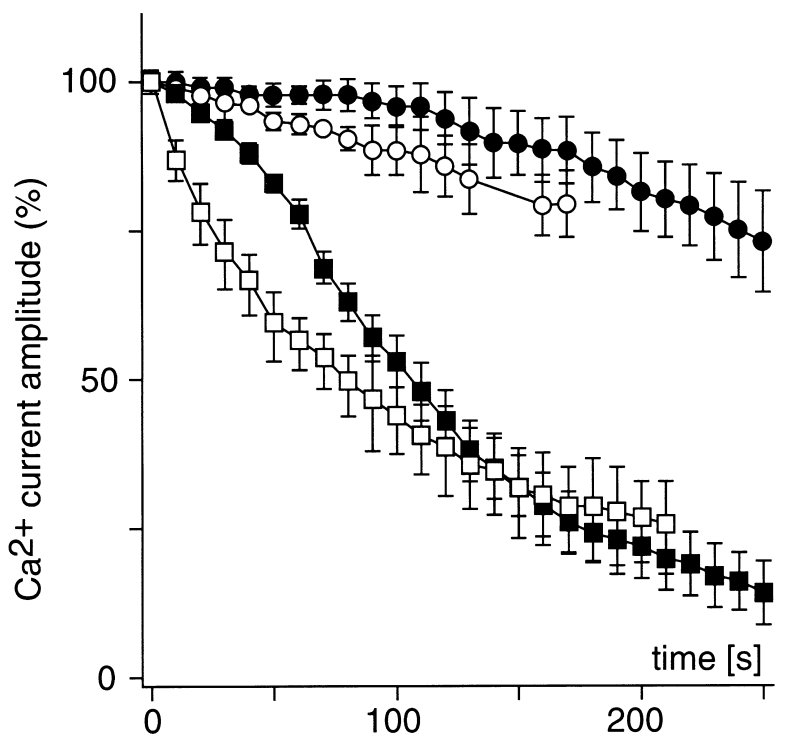

Fig. 5. Rundown of $\mathrm{Ca}^{2+}$ channels in a chicken DRG neuron. (A) $\mathrm{Ca}^{2+}$ currents were evoked by $50-\mathrm{ms}$ depolarizations to $0 \mathrm{mV}$ every $10 \mathrm{~s}$. Every third current trace is shown. This neuron was perfused with a $\mathrm{Ca}^{2+}$ buffer containing $3 \mathrm{mM} \mathrm{Ca}{ }^{2+} / 5 \mathrm{mM}$ EGTA $\left(\left[\mathrm{Ca}^{2+}\right]_{\mathrm{i}} \approx 200 \mathrm{nM}\right.$ at $\mathrm{pH}$ 7.30). $\mathrm{Ca}^{2+}$ current amplitudes were reduced by $80 \%$ within 3 min of whole-cell recording. (B) The time-course of the rundown process of $\mathrm{Ca}^{2+}$ currents. Cells were perfused either with virtually $\mathrm{Ca}^{2+}$-free internal solution (5 mM EGTA/0 $\mathrm{Ca}^{2+}$, circles) or with $200 \mathrm{nM}$ free $\mathrm{Ca}^{2+}(5 \mathrm{mM}$ EGTA/3 $\mathrm{mM} \mathrm{Ca}^{2+}$, rectangles). Open and filled symbols represent recordings in the presence or absence of external FK506 $(1 \mu \mathrm{M})$, respectively (means \pm S.E.M., $n=3-6$ ).

This finding could be explained by the observation that FK506 and cyclosporin A increase both resting and 4-aminopyridine-stimulated intrasynaptosomal $\mathrm{Ca}^{2+}$ concentrations, and facilitate the $\mathrm{Ca}^{2+}$-dependent release of the excitatory neurotransmitter L-glutamate from rat brain synaptosomes. ${ }^{38}$ These two findings suggest a presynaptic site of action and support a role for $\mathrm{CaN}$ also in the regulation of $\mathrm{N}$ - and $\mathrm{P}$-type $\mathrm{Ca}^{2+}$ channels, which trigger the release of neurotransmitters. ${ }^{14}$ Such an interaction of $\mathrm{CaN}$ with $\mathrm{N}$-type $\mathrm{Ca}^{2+}$ channels is further supported by an immunocytochemical study, which demonstrates the co-localization of $\mathrm{CaN}$ with $\mathrm{Ca}^{2+}$ channels in DRG neurons. ${ }^{31}$

Previous studies, which have used the immunosuppressive drugs FK506 and cyclosporin A, have provided evidence both for and against an involvement of $\mathrm{CaN}$ in the $\mathrm{Ca}^{2+}$-dependent inactivation of $\mathrm{Ca}^{2+}$ channels. In a recent study, ${ }^{42}$ no 
experimental evidence was obtained that supported an involvement of $\mathrm{CaN}$. The significance of this negative result, however, critically depends on the presence of the intracellular binding proteins, i.e. FKBPs and cyclophilins, in the cytoplasm, and on the ability of these proteins to interact with CaN. In a developmental study, Polli et al. ${ }^{35}$ have suggested that, in the developing rat brain, $\mathrm{CaN}$ immunoreactivity is not detectable until postnatal day 4 and developmental changes in neuronal FKBP expression cannot be ruled out. Our study clearly shows that $\mathrm{CaN}$ and FKBP-12 are expressed in embryonic chick DRG neurons and undifferentiated $\mathrm{GH}_{3}$ cells. Positive evidence for the involvement of $\mathrm{CaN}$ has recently been provided by Lukyanetz et al. ${ }^{32}$ in a rodent neuroblastoma $\times$ glioma cell line, but it is not clear whether this process is of physiological significance in differentiated neurons. A possible mechanism that might explain these divergent results could be that the susceptibility of the $\mathrm{Ca}^{2+}$ channel proteins to modulation by $\mathrm{CaN}$ depends on the developmental stage, e.g., on the occurrence of different splice variants of L- ${ }^{37}$ or $\mathrm{N}$-type ${ }^{28,29} \mathrm{Ca}^{2+}$ channels or of different combinations of $\alpha$ and $\beta \mathrm{Ca}^{2+}$ channel subunits. ${ }^{8}$

In the present paper, we provide further evidence that $\mathrm{CaN}$ is not involved in the inactivation process of L-type $\mathrm{Ca}^{2+}$ channels in $\mathrm{GH}_{3}$ cells and of N-type channels in chicken DRG neurons, although both cell types have $\mathrm{CaN}$ and FKBP-12 in their cytoplasm. To exclude the possibility that FKBP might be washed out from the cytoplasm, we have performed perforated-patch recordings in $\mathrm{GH}_{3}$ cells which prevent such a washout of macromolecules. In chicken DRG neurons, we have used conventional whole-cell recordings, which allowed us to perfuse the cells with a known concentration of FK506 and also with the complex of FK506 and FKBP. Our results therefore provide direct evidence against a significant contribution of $\mathrm{CaN}$ to the $\mathrm{Ca}^{2+}$-dependent inhibition of $\mathrm{L}$ - and N-type channels. An alternative pathway that may account for the $\mathrm{Ca}^{2+}$-dependent inactivation of $\mathrm{Ca}^{2+}$ channels is the direct interaction of $\mathrm{Ca}^{2+}$ ions with the channel protein. ${ }^{34,46}$ Such a direct binding of $\mathrm{Ca}^{2+}$ ions has been proposed by Gutnick et al. ${ }^{17}$ for molluscan $\mathrm{Ca}^{2+}$ channels. de Leon et al. ${ }^{11}$ and Imredy and $\mathrm{Yue}^{23}$ have recently provided evidence for such a direct effect on native and artificially expressed cardiac L-type $\mathrm{Ca}^{2+}$ channels, and similar mechanisms may also exist in neuronal Land $\mathrm{N}$-type $\mathrm{Ca}^{2+}$ channels. In summary, our results provide strong evidence against the involvement of $\mathrm{CaN}$ in the inactivation process of $\mathrm{L}-$ and $\mathrm{N}$-type $\mathrm{Ca}^{2+}$ channels, and support the dominant role of direct binding of $\mathrm{Ca}^{2+}$ ions to the channels.

Acknowledgements - This work was supported in part by the Deutsche Forschungsgemeinschaft to H.U.Z. (Ze 377/4-1 and SFB 353/A8), W.N. (SFB 353/B9) and D.S. (SFB 353/A2). We thank Mrs Anita Hecht, Mrs Susanne Schmidt and Mrs Christiane Wittek for excellent technical assistance.

\section{REFERENCES}

1. Ahlijanian M. K., Striessnig J. and Catterall W. A. (1991) Phosphorylation of an alpha 1-like subunit of an omega-conotoxin-sensitive brain calcium channel by cAMP-dependent protein kinase and protein kinase. J. biol. Chem. 266, 20,192-20,197.

2. Allen T. J. A. and Chapman R. A. (1995) The effect of a chemical phosphatase on single calcium channels and the inactivation of whole-cell calcium currents from isolated guinea-pig ventricular myocytes. Pflügers Arch. 430, 68-80.

3. Anwyl R. (1991) Modulation of vertebrate neuronal calcium channels by transmitters. Brain Res. Rev. 16, $265-281$.

4. Armstrong D. L. (1989) Calcium channel regulation by calcineurin, a $\mathrm{Ca}^{2+}$-activated phosphatase in mammalian brain. Trends Neurosci. 12, $117-122$.

5. Armstrong D. and Eckert R. (1987) Voltage-activated calcium channels that must be phosphorylated to respond to membrane depolarization. Proc. natn. Acad. Sci. U.S.A. 84, 2518-2522.

6. Byerly L. and Hagiwara S. (1982) Calcium currents in internally perfused nerve cell bodies of Limnea stagnalis. J. Physiol. 322, 503-528.

7. Carbone E. and Swandulla D. (1989) Neuronal calcium channels: kinetics, blockade and modulation. Prog. Biophys. molec. Biol. 54, 31-58.

8. Cens T., Restituito S. and Charnet P. (1999) Regulation of Ca-sensitive inactivation of an L-type Ca ${ }^{2+}$ channel by specific domains of beta subunits. Fedn Eur. biochem. Socs Lett. 450, 17-22.

9. Chad J. E. and Eckert R. (1986) An enzymatic mechanism for calcium current inactivation in dialysed Helix neurones. J. Physiol. 378, 31-51.

10. Charters A. R., Kobayashi M. and Butcher S. P. (1995) Developmental expression of FK506 binding proteins and calcineurin in rat brain. Biochem. Soc. Trans. 23, 422S.

11. de Leon M., Wang Y., Jones L., Perez-Reyes E., Wei X., Soong T. W., Snutch T. P. and Yue D. T. (1995) Essential Ca ${ }^{2+}$-binding motif for Ca ${ }^{2+}$-sensitive inactivation of L-type $\mathrm{Ca}^{2+}$ channels. Science 270, 1502-1506.

12. Doroshenko P. A., Kostyuk P. G. and Martynyuk A. E. (1982) Intracellular metabolism of adenosine $3^{\prime}, 5^{\prime}$-cyclic monophosphate and calcium inward current in perfused neurones of Helix pomatia. Neuroscience 7, 2125-2134.

13. Dunlap K. and Ikeda S. R. (1998) Receptor-mediated pathways that modulate calcium channels. Semin. Neurosci. 9, $198-208$.

14. Dunlap K., Luebke J. I. and Turner T. J. (1995) Exocytotic Ca ${ }^{2+}$ channels in mammalian central neurons. Trends Neurosci. 18, 89-98.

15. Fenwick E. M., Marty A. and Neher E. (1982) Sodium and calcium channels in bovine chromaffin cells. J. Physiol. 331, 599-635.

16. Gibbons S. J., Brorson J. R., Bleakman D., Chard P. S. and Miller R. J. (1993) Calcium influx and neurodegeneration. Ann. N. Y. Acad. Sci. 679, $22-33$.

17. Gutnick M. J., Lux H. D., Swandulla D. and Zucker H. (1989) Voltage-dependent and calcium-dependent inactivation of calcium channel current in identified snail neurones. J. Physiol. 412, 197-220.

18. Hamid J., Nelson D., Spaetgens R., Dubel S. J., Snutch T. P. and Zamponi G. W. (1999) Identification of an integration center for cross-talk between protein kinase $\mathrm{C}$ and $\mathrm{G}$ protein modulation of N-type calcium channels. J. biol. Chem. 274, 6195-6202.

19. Hamill O. P., Marty A., Neher E., Sakmann B. and Sigworth F. J. (1981) Improved patch-clamp techniques for high-resolution current recording from cells and cell-free membrane patches. Pflügers Arch. 391, 85-100.

20. Hell J. W., Appleyard S. M., Yokoyama C. T., Warner C. and Catterall W. A. (1994) Differential phosphorylation of two size forms of the N-type calcium channel alpha 1 subunit which have different COOH termini. J. biol. Chem. 269, 7390-7396.

21. Hell J. W., Yokoyama C. T., Breeze L. J., Chavkin C. and Catterall W. A. (1995) Phosphorylation of presynaptic and postsynaptic calcium channels by cAMP-dependent protein kinase in hippocampal neurons. Eur. molec. Biol. Org. J. 14, 3036-3044.

22. Horn R. and Marty A. (1988) Muscarinic activation of ionic currents measured by a new whole-cell recording method. J. gen. Physiol. 92, $145-159$.

23. Imredy J. P. and Yue D. T. (1994) Mechanism of $\mathrm{Ca}^{2+}$-sensitive inactivation of L-type Ca ${ }^{2+}$ channels. Neuron 12, $1301-1318$.

24. Kalman D., O’Lague P. H., Erxleben C. and Armstrong D. L. (1988) Calcium-dependent inactivation of the dihydropyridine-sensitive calcium channels in $\mathrm{GH}_{3}$ cells. J. gen. Physiol. 92, 531-548.

25. Kasai H. and Neher E. (1992) Dihydropyridine-sensitive and omega-conotoxin-sensitive calcium channels in a mammalian neuroblastoma-glioma cell line. J. Physiol., Lond. 448, 161-188. 
26. Klee C. B., Crouch T. H. and Krinks M. H. (1979) Calcineurin: a calcium- and calmodulin-binding protein of the nervous system. Proc. natn. Acad. Sci. U.S.A. 76, 6270-6273.

27. Kostyuk P. G., Veselovsky N. S. and Fedulova S. A. (1981) Ionic currents in the somatic membrane of rat dorsal root ganglion neurons-II. Calcium currents. Neuroscience 6, 2431-2437.

28. Lin Z., Lin Y., Schorge S., Pan J. Q., Beierlein M. and Lipscombe D. (1999) Alternative splicing of a short cassette exon in alpha1B generates functionally distinct N-type calcium channels in central and peripheral neurons. J. Neurosci. 19, 5322-5331.

29. Lin Z., Haus S., Edgerton J. and Lipscombe D. (1997) Identification of functionally distinct isoforms of the N-type Ca ${ }^{2+}$ channel in rat sympathetic ganglia and brain. Neuron 18, 153-166.

30. Liu J., Farmer J. D. Jr, Lane W. S., Friedman J., Weissman I. and Schreiber S. L. (1991) Calcineurin is a common target of cyclophilin-cyclosporin A and FKBP-FK506 complexes. Cell 66, 807-815.

31. Lukyanetz E. A. (1997) Evidence for colocalization of calcineurin and calcium channels in dorsal root ganglion neurons. Neuroscience 78, 625-628.

32. Lukyanetz E. A., Piper T. P. and Sihra T. S. (1998) Calcineurin involvement in the regulation of high-threshold Ca ${ }^{2+}$ channels in NG108-15 (rodent neuroblastoma $\times$ glioma hybrid) cells. J. Physiol., Lond. 510, 371-385.

33. McNaughton N. C., Bleakman D. and Randall A. D. (1998) Electrophysiological characterisation of the human N-type Ca ${ }^{2+}$ channel. II. Activation and inactivation by physiological patterns of activity. Neuropharmacology 37, 67-81.

34. Noceti F., Olcese R., Qin N., Zhou J. and Stefani E. (1998) Effect of Bay K 8644(-) and the $\beta_{2 a}$ subunit on Ca ${ }^{2+}-$ dependent inactivation in $\alpha_{1 \mathrm{C}}$ Ca ${ }^{2+}$ channels. J. gen. Physiol. 111, 463-475.

35. Polli J. W., Billingsley M. L. and Kincaid R. L. (1991) Expression of the calmodulin-dependent protein phosphatase, calcineurin, in rat brain: developmental patterns and the role of nigrostriatal innervation. Devl Brain Res. 63, 105-119.

36. Simasko S. M., Weiland G. A. and Oswald R. E. (1988) Pharmacological characterization of two calcium currents in GH 3 cells. Am. J. Physiol. 254, E328-E336.

37. Soldatov N. M., Zuhlke R. D., Bouron A. and Reuter H. (1997) Molecular structures involved in L-type calcium channel inactivation. Role of the carboxyl-terminal region encoded by exons 40-42 in alpha1C subunit in the kinetics and $\mathrm{Ca}^{2+}$ dependence of inactivation. J. biol. Chem. 272, 3560-3566.

38. Steiner J. P., Dawson T. M., Fotuhi M. and Snyder S. H. (1996) Immunophilin regulation of neurotransmitter release. Molec. Med. 2, 325-333.

39. Swandulla D. and Armstrong C. M. (1988) Fast-deactivating calcium channels in chick sensory neurons. J. gen. Physiol. 92, $197-218$.

40. Swandulla D. and Zeilhofer H. U. (1998) Calcium regulation of ion channels. In Integrative Aspects of Calcium Signalling (eds Verkhratsky A. and Toescu E. C.), pp. 79-97. Plenum, New York.

41. Tsien R. W., Bean B. P., Hess P., Lansman J. B., Nilius B. and Nowycky M. C. (1986) Mechanisms of calcium channel modulation by beta-adrenergic agents and dihydropyridine calcium agonists. J. molec. cell. Cardiol. 18, 691-710.

42. Victor R. G., Rusnak F., Sikkink R., Marban E. and O'Rourke B. (1997) Mechanism of Ca ${ }^{2+}$-dependent inactivation of L-type Ca ${ }^{2+}$ channels in GH 3 cells: direct evidence against dephosphorylation by calcineurin. J. Membrane Biol. 156, 53-61.

43. Victor R. G., Thomas G. D., Marban E. and O'Rourke B. (1995) Presynaptic modulation of cortical synaptic activity by calcineurin. Proc. natn. Acad. Sci. U.S.A. 92, 6269-6273.

44. Werz M. A., Elmslie K. S. and Jones S. W. (1993) Phosphorylation enhances inactivation of N-type calcium channel current in bullfrog sympathetic neurons. Pflügers Arch. 424, 538-545.

45. Yue D. T., Herzig S. and Marban E. (1990) Beta-adrenergic stimulation of calcium channels occurs by potentiation of high-activity gating modes. Proc. natn. Acad. Sci. U.S.A. 87, 753-757.

46. Zühlke R. D. and Reuter H. (1998) $\mathrm{Ca}^{2+}$-sensitive inactivation of L-type $\mathrm{Ca}^{2+}$ channels depends on multiple cytoplasmatic amino acid sequences of the $\alpha_{1 C}$. Proc. natn. Acad. Sci. U.S.A. 95, 3287-3294. 